\title{
The Readers of the National Library of Russia in XIX - Beginning of XXI Century
}

\section{Čitalačka publika Nacionalne biblioteke Rusije u 19. i početkom 21. stoljeća}

\author{
Anton Likhomanov ${ }^{1}$, Kseniia Morozova ${ }^{2}$ \\ The National Library of Russia, Saint-Petersburg, Russia / Nacionalna biblioteka Rusije, Sankt Peterburg, Rusija \\ 1'a.likhomanov@nlr.ru, ${ }^{2}$ morozovakb@nlr.ru
}

\section{Article Info / Informacije o članku}

Primljen / Received 14. 9. 2020.

Prihvaćen / Accepted 9. 10. 2020

Dostupan online / Available online: 15. 12. 2020.

Keywords / Ključne riječi:

the National Library of Russia, readers

Nacionalna Biblioteka Rusije, čitalačka publika

\begin{abstract}
Sažetak
This article explores the evolution of the audience of the National Library of Russia (NLR) from the beginning of the XIX century until the present day. The author demonstrates how political and economic factors influenced social and gender characteristics of readers of the NLR, increase in the amount of readers, strengthening of the role of the library as one of the largest cultural and information centers in the world.
\end{abstract}

Ovaj članak istražuje razvoj publike Nacionalne biblioteke Rusije (NBR) od početka 19. stoljeća do danas. Autori pokazuju kako su politički i ekonomski činioci utjecali na socijalne i rodne karakteristike čitalačke publike NBR-a, povećanje broja čitatelja, jačanje uloge biblioteke kao jednog od najvećih kulturnih i informacijskih centara na svijetu.
The history of any national library cannot be fully objective without information about its readers at different periods of time. Studying who were the readers of the library gives an opportunity to better understand the impact the library had on the development of the country.

The Imperial Public Library - now the National Library of Russia (NLR) was founded in 1795 and opened for general public in 1814 in the building specially constructed for these purposes in the centre of St. Petersburg - at the time, the capital of Russia. The Academy of Sciences, the Academy of Arts, as well as several higher education institutions, ministries and government departments have been situated in the city. There was a need for a free library with a universal collection of documents, formed by the legal deposit of all publications printed in the country - that is why the NLR has been created. No other library that existed in St. Petersburg at the time has met these requirements. The library of the Academy of Sciences was open only two days a week from 2 to 4 p.m., and only teachers and students could borrow books from libraries of educational institutions, and it was too expensive to use the private libraries at the bookstores ${ }^{1}$.

During the early years of the Library's work there were not only academicians among the readers, but

Efimova N.A. 1958. "Chitateli Publichnoj biblioteki v Peterburge i organizaciya ih obsluzhivaniya v 1814-1917 gg." in Trudy Gosudarstvennoj publichnoj biblioteki im. M.E. SaltykovaShchedrina. Vol.6(9). (Leningrad, 1958, 13)
Historija bilo koje nacionalne biblioteke ne može biti potpuno objektivna bez podataka o svojoj čitateljskoj publici u različitim vremenskim razdobljima. Proučavanje, ko su bili čitatelji biblioteke, daje priliku da se bolje razumije utjecaj koji je biblioteka imala na razvoj zemlje.

Carska javna biblioteka - danas Nacionalna biblioteka Rusije (NBR) osnovana je 1795. godine, a otvorena je za širu javnost 1814. godine u zgradi posebno izgrađenoj za te svrhe u središtu Sankt-Peterburga - $u$ to vrijeme glavnog grada Rusije. U gradu su bile smještene Akademija nauka, Akademija umjetnosti, kao i nekoliko visokoškolskih ustanova, ministarstava i vladinih odjela. Postojala je potreba za besplatnom bibliotekom $\mathrm{s}$ univerzalnom zbirkom dokumenata, formiranom obaveznim primjerkom svih publikacija štampanih u zemlji - te je zato i stvorena NBR. Nijedna druga biblioteka koja je postojala $u$ to vrijeme $u$ Sankt Peterburgu nije ispunjavala ove uslove. Biblioteka Akademije nauka bila je otvorena samo dva dana u sedmici od 14 do 16 sati, i samo su učitelji i studenti mogli posuđivati knjige iz biblioteka obrazovnih institucija, a bilo je preskupo koristiti privatne biblioteke u knjižarama. ${ }^{1}$ Tokom ranih godina rada Biblioteke među čitateljima nisu bili samo akademici, već i drugi obrazovani ljudi toga doba koji su trebali knjige u akademske,

Efimova N.A. 1958. “Čitateli Publičnoj biblioteki v Peterburge i organizacija ih obsluživanija v 1814-1917 gg." u Trudy Gosudarstvennoj publičnoj biblioteki im. M.E. Saltykova-Šedrina. T.6(9). (Leningrad, 1958, 13) 
also other educated people of that time who needed books for academic, professional or educational purposes. In the report for the year 1816 it was mentioned, that in the reading room one could see "people of all estates".

The information on categories of readers according to estates and professions during the early years of the library's work (specifically 1816-1819) has been preserved the best: ${ }^{3}$ profesionalne ili obrazovne svrhe. U izvještaju za 1816. godinu spomenuto je da se u čitaonici mogu vidjeti „ljudi svih staleža”. ${ }^{2}$

Podaci o kategorijama čitatelja prema staležima i zanimanjima tokom ranih godina rada Biblioteke (konkretno 1816. - 1819.) najbolje su očuvani: ${ }^{3}$

\begin{tabular}{|c|c|c|c|c|c|c|c|c|}
\hline & \multicolumn{2}{|c|}{1816} & \multicolumn{2}{|c|}{1817} & \multicolumn{2}{|c|}{1818} & \multicolumn{2}{|c|}{1819} \\
\hline & $\begin{array}{c}\text { Amount / } \\
\text { Broj }\end{array}$ & $\%$ & $\begin{array}{c}\text { Amount / } \\
\text { Broj }\end{array}$ & $\%$ & $\begin{array}{c}\text { Amount / } \\
\text { Broj }\end{array}$ & $\%$ & $\begin{array}{c}\text { Amount / } \\
\text { Broj }\end{array}$ & $\%$ \\
\hline Civilians / Civili & 225 & 43,9 & 252 & 41,6 & 184 & 44,1 & 266 & 44,1 \\
\hline Military officials / Vojni zvaničnici & 118 & 23,0 & 117 & 19,3 & 63 & 15,1 & 118 & 19,8 \\
\hline Students and pupils / Studenti i učenici & 69 & 13,4 & 121 & 20,0 & 102 & 24,5 & 113 & 18,9 \\
\hline Merchants and bourgeois / Trgovci i buržuji & 22 & 4,2 & 23 & 3,8 & 13 & 3,1 & 13 & 2,1 \\
\hline $\begin{array}{l}\text { Scholars (doctors, professors, masters) / } \\
\text { Učenjaci (doktori, profesori, magistri) }\end{array}$ & 10 & 2,0 & 22 & 3,6 & 7 & 1,7 & 9 & 1,5 \\
\hline Artists / Umjetnici & - & - & 8 & 1,3 & 2 & 0,5 & 5 & 0,8 \\
\hline Peasants / Seljaci & - & - & - & - & 1 & 0,2 & - & - \\
\hline Clergy / Kler & 8 & 1,5 & 4 & 0,7 & 3 & 0,7 & 3 & 0,5 \\
\hline Other / Ostali & 60 & 12,0 & 59 & 9,7 & 42 & 10,1 & 73 & 12,3 \\
\hline In total / Ukupno & 512 & 100 & 606 & 100 & 417 & 100 & 600 & 100 \\
\hline
\end{tabular}

It is important to mention that there were no access limitations in the rules of the Library: anyone who wanted to work in the Library could register at the desk of the librarian, who gave tickets for free entry. Footmen in uniforms were supposed to wait for their masters in the hall. ${ }^{4}$

During the summertime the Library was open for visits on Wednesdays, Thursdays, and Fridays from 10 a.m. to 9 p.m., and in winter - from 10 a.m. till sunset (taking into account that St. Petersburg is a Northern city it could happen at 5, 4 or 3 p.m.). Also every Tuesday from 11 a.m. to 2 p.m. people could visit the Library to look around and order literature for the next few days. It was not permitted to borrow books from the Library. ${ }^{5}$

Note that there were no recommendations needed to register in the Imperial Public Library (unlike, for example, the British Library).

Soon after the opening of the Library there were several rules established on how to work with the col-

${ }^{4}$ Grin C.I., Tret'yak A.M. 1998. Publichnaya biblioteka glazami sovremennikov (1795-1917). (Saint Petersburg, 1998, 79-84)

5 Ibid, 82
}

Važno je napomenuti da u pravilima Biblioteke nisu postojala ograničenja pristupa: svako ko je želio raditi u Biblioteci mogao se prijaviti na stolu bibliotekara koji je davao ulaznice za besplatan ulaz. Lakaji u uniformama su trebali čekati svoje gospodare u dvorani. ${ }^{4}$

Tokom ljeta Biblioteka je bila otvorena za posjet srijedom, četvrtkom i petkom od 10 sati do 21 sat, a zimi - od 10 sati do zalaska sunca (uzimajući u obzir da je Sankt-Peterburg sjeverni grad, to bi se moglo dogoditi u 17, 16 ili 15 sati). Također svakog utorka od 11 sati do 14 sati ljudi bi mogli posjetiti Biblioteku kako bi razgledali i naručili literaturu za sljedećih nekoliko dana. Nije bilo dopušteno posuđivati knjige iz Biblioteke. ${ }^{5}$

Imajte na umu da nisu bile potrebne preporuke za prijavljivanje u Carsku javnu biblioteku (za razliku od, primjerice, Britanske biblioteke).

\footnotetext{
Ibid, 17

3 Ibid, 17

4 Grin C.I., Tret'jak A.M. 1998. Publičnaja biblioteka glazami sovremennikov (1795-1917). (Sankt-Peterburg.1998., 79-84)

5 Ibid, 82
} 
lection: readers no longer had access to fiction, fairytales, periodicals, political editions, as well as editions "harmful for morality". The officials believed that the readers should come to the Library only for academic work and to gain "useful knowledge". ${ }^{6}$

This rule along with the inconvenient work hours negatively influenced the attendance of the Library. Only in 1848 reading rooms started to work every day (on Sundays and holidays - from 12 p.m. to 3 p.m.). In 1846 entrance to the library was forbidden for lower military officers; also the students of secondary educational institutions had to get a special permission.

The majority of visitors of the Library in the first half of XIX century were civilians. ${ }^{7}$

The data on the work of the reading room in 1814$18500^{8}$
Ubrzo nakon otvaranja Biblioteke uspostavljeno je nekoliko pravila o radu s zbirkom: čitatelji više nisu imali pristup fikciji, bajkama, periodici, političkim izdanjima, kao ni izdanjima "štetnim za moral". Službenici su vjerovali da bi čitatelji trebali dolaziti u biblioteku samo radi akademskog rada i sticanja "korisnog znanja". ${ }^{6}$

Ovo je pravilo, zajedno s nezgodnim radnim vremenom, negativno utjecalo na posjećenost Biblioteke. Tek 1848. čitaonice su počele raditi svaki dan (nedjeljom i praznicima - od 12 do 15 sati). 1846. godine ulaz u biblioteku bio je zabranjen nižim vojnim časnicima; također su učenici drugostepenih obrazovnih ustanova morali dobiti posebno dopuštenje. Većina posjetitelja Biblioteke u prvoj polovici 19. stoljeća bili su civili. ${ }^{7}$

Podaci o radu čitaonice u 1814-1850:8

\begin{tabular}{|c|c|c|}
\hline \multirow{2}{*}{$\begin{array}{c}\text { Years } \\
\text { Godine }\end{array}$} & $\begin{array}{c}\text { Amount of issued tickets } \\
\text { Zbir izdatih ulaznica }\end{array}$ & $\begin{array}{c}\text { Issuance of literature } \\
\text { Izdavanje literature }\end{array}$ \\
\cline { 2 - 3 } & \multicolumn{2}{|c|}{ On average annually / Godišnji prosjek } \\
\hline 1814 & 969 & 1341 \\
\hline $1815-1832$ & 458 & 2280 \\
\hline $1833-1834$ & \multicolumn{2}{|c|}{$\begin{array}{c}\text { The Library is closed because of construction works } \\
\text { Biblioteka je zatvorena zbog gradevinskih radova }\end{array}$} \\
\hline 1835 & 651 & 3275 \\
\hline $1836-1840$ & 813 & 6540 \\
\hline $1841-1845$ & 887 & 7087 \\
\hline $1846-1850$ & 848 & 10716 \\
\hline
\end{tabular}

In general, the audience of the Library in the first half of XIX century demonstrates that the level of education in the country was rather low at the time, and therefore - there was small demand for qualified specialists.

There was a noticeable change in that regard in the second half of XIX century. It was a period of economic growth in Russia, as well as important social changes: in 1861 serfdom was abolished, in 1860-70s the trial by jury was introduced, and the new system of public authorities and conscript army. The national economy required much more educated people who possessed professional skills than before. That

\footnotetext{
6 Efimova N.A. 1958. "Chitateli Publichnoj biblioteki v Peterburge i organizaciya ih obsluzhivaniya v 1814-1917 gg." in Trudy Gosudarstvennoj publichnoj biblioteki im. M.E. SaltykovaShchedrina. Vol.6(9). (Leningrad, 1958, 14-15)

7 Istoriya Gosudarstvennoj Publichnoj biblioteki im. M.E. SaltykovaShchedrina. 1963. Leningrad. (Lenizdat, 1963, 41-42)

8 Ibid, 41
}

Općenito, korisnici Biblioteke u prvoj polovici 19. stoljeća pokazuju da je u to vrijeme razina obrazovanja u zemlji bila prilično niska, a samim time - postojala je mala potražnja za kvalificiranim stručnjacima.

U tom pogledu došlo je do primjetne promjene $u$ drugoj polovici 19. stoljeća. Bilo je to razdoblje gospodarskog rasta u Rusiji, kao i važnih društvenih promjena: 1861. godine ukinuto je kmetstvo, u 1860-70im uvedeno je suđenje porote i novi sistem javnih vlasti i obveznika. Nacionalno gospodarstvo zahtijevalo je mnogo obrazovanije ljude koji su posjedovali profesionalne vještine nego prije. To je dovelo do povećanja broja studenata - budućih in-

\footnotetext{
${ }_{6}$ Efimova N.A. 1958. "Čitateli Publičnoj biblioteki v Peterburge i organizacija ih obsluživanija v 1814-1917 gg." u Trudy Gosudarstvennoj publičnoj biblioteki im. M.E. Saltykova-Šedrina. T.6(9). (Leningrad, 1958, 14-15)

7 Istorija Gosudarstvennoj Publičnoj biblioteki im. Saltykova-Šedrina. 1963. Leningrad. (Lenizdat, 1963, 41-42)

8 Ibid, 41
} 
led to the increase in the amount of students - the future engineers, lawyers, economists, teachers etc.

The major tendency among the audience of the Library was increase in the number of students and decrease in some other categories of visitors, mainly, civilians. While in 1853-1861 the rate of civilians was on average at $25 \%$, in 1862-1895 it was only $9,8 \%$. At the same time during this period the amount of students was higher than $26 \%$, most of them - the students of the universities of St. Petersburg. Simultaneously, the amount of teachers increased as well: whereas in 1853 only 22 professors and teachers had been registered in the Library, in 1867 their number grew to 225 , and in 1895 - to 646 people.

Talking about the social aspect, only $20-30 \%$ of readers indicated their social category. It is important to remember, that at the time the Russian Empire was a class-divided society, with nobility as the upper class.

The following table shows the increase in the number of readers from under-privileged social classes: ${ }^{9}$ ženjera, pravnika, ekonomista, nastavnika itd.

Glavna tendencija korisnika u biblioteci bila je povećanje broja učenika i smanjenje nekih drugih kategorija posjetitelja, uglavnom civila. Dok je u razdoblju 1853.-1861. stopa civila bila u prosjeku $25 \%$, u razdoblju 1862.-1895. bila je samo 9,8\%. Istodobno je u tom razdoblju broj studenata bio veći od $26 \%$, većina njih - studenata sveučilišta u Sankt Peterburgu. Istodobno se povećavao i broj učitelja: dok su 1853. godine u Biblioteci bila prijavljena samo 22 profesora i učitelja, 1867. njihov je broj narastao na 225, a 1895. na 646 ljudi.

Govoreći o socijalnom aspektu, samo je 20-30\% čitatelja naznačilo svoju socijalnu kategoriju. Važno je zapamtiti da je u to vrijeme Rusko Carstvo bilo klasno podijeljeno društvo, s plemstvom kao gornjom klasom.

Sljedeća tablica prikazuje porast broja čitatelja iz siromašnih društvenih slojeva: ${ }^{9}$

\begin{tabular}{|l|c|c|c|c|c|c|c|c|}
\hline & $1855-1859$ & $1860-1864$ & $1865-1869$ & $1870-1874$ & $1875-1879$ & $1880-1884$ & $1885-1889$ & $1890-1894$ \\
\hline $\begin{array}{l}\text { Merchants, bourgeois and } \\
\text { peasants } \\
\text { Trgovci, buržuji i seljaci }\end{array}$ & 1067 & 2100 & 4681 & 5754 & 6673 & 7556 & 7130 & 6823 \\
\hline
\end{tabular}

An important event in the life of the Library was that female readers were allowed to visit it. In 1856 the first open education institutions for women were created in Russia, and in 1878 the first higher education institution for women has been opened - Higher (Bestuzhev) Courses in St. Petersburg. In 1870 the per cent of women among the readers was $5,4 \%$, in $1895-17,8 \%$. They were teachers, students, doctors, medical attendants, nurses, pharmacists, artists and performers. ${ }^{10}$ The reasons for their visits were the professional interests, studying, work. As the newspaper "Peterburgskiy listok" put it: "It is pleasant to see that women dedicate their free time to reading in the room that was specially made for that purpose, and that they are predominantly interested in serious books and foreign publications, as for many of them translation is the only source of livehood". ${ }^{11}$

Due to the increase in acquisition in the second half of XIX century, construction of two new reading

\footnotetext{
9 Efimova N.A. 1958. "Chitateli Publichnoj biblioteki v Peterburge i organizaciya ih obsluzhivaniya v 1814-1917 gg." in Trudy Gosudarstvennoj publichnoj biblioteki im. M.E. SaltykovaShchedrina. Vol.6(9). (Leningrad, 1958, 40-44)

10 Ibid, 45-46

11 Grin C.I., Tret'yak A.M. 1998. Publichnaya biblioteka glazami sovremennikov (1795-1917). (Saint Petersburg, 1998, 411)
}

Važan događaj u životu Biblioteke bio je taj da su je čitateljice smjele posjetiti. 1856. godine u Rusiji su stvorene prve otvorene ženske obrazovne ustanove, a 1878. godine otvorena je prva ženska visokoškolska institucija - Viši (Bestužev) kursevi u Sankt Peterburgu. 1870. godine postotak žena među čitateljskoj publici iznosio je $5,4 \%$, a 1895 . - $17,8 \%$. Bile su to učiteljice, studentice, doktorice, medicinske djelatnice, medicinske sestre, farmaceutkinje, umjetnice i izvođačice. ${ }^{10}$ Razlozi njihovih posjeta bili su profesionalni interesi, studiranje, posao. Kao što su napisale novine „Peterburgskij listok“: „Ugodno je vidjeti da žene svoje slobodno vrijeme posvećuju čitanju u sobi koja je bila posebno stvorena za tu svrhu i da su pretežno zainteresirane za ozbiljne knjige i strane publikacije, pogotovo što je za mnoge od njih prevođenje jedini izvor sredstava za život". ${ }^{11}$

Zbog porasta nabavke u drugoj polovici 19. stoljeća, izgradnje dviju novih čitaonica kao i modernih

\footnotetext{
9 Efimova N.A. 1958. "Čitateli Publičnoj biblioteki v Peterburge i organizacija ih obsluživanija v 1814-1917 gg." u Trudy Gosudarstvennoj publičnoj biblioteki im. M.E. Saltykova-Šedrina. T.6(9). (Leningrad, 1958, 40-44)

${ }^{10}$ Ibid, 45-46

${ }^{11}$ Grin C.I., Tret'jak A.M. 1998. Publičnaja biblioteka glazami sovremennikov (1795-1917). (Sankt-Peterburg.1998., 411)
} 
rooms as well as modern stacks and allowing the readers to get fiction and some other types of publications the NLR managed to increase the attendance and consequently - the circulation from 15110 of visits and 27587 loans in 1852 to 145366 visits and 461968 loans in 1900. ${ }^{12}$ All of that led to the enhancement of the Library's role in the academic, cultural and public life of Russia.

In the second half of XIX century Russian revolutionaries as Vladimir Lenin and Georgiy Plekhanov, outstanding Russian scientists, artists and composers were among the readers of the Library.

In the beginning of the XX century the following tendencies continued developing: in 1896-1916 the amount of students among the readers of the Library was $33,8 \%$. The number of students decreased only in 1916 when many of them have been called up for military service during the World War I.

In 1896-1916 the amount of civilians among the readers decreased from $9,8 \%$ to $6,8 \%$, military officers - from $6,9 \%$ to $2,8 \%$. At the same time the number of medical workers, teachers, as well as engineers and technical specialists grew. The number of female readers was also increasing. ${ }^{13}$

The Revolution of 1917 and the Civil War of 19181920 that followed caused significant changes in all spheres of life in Russia. One of the goals of the Communist party that came to power was the Cultural Revolution that implied the liquidation of illiteracy, preparing the qualified professionals for manufacturing industry and agricultural sector as well as the development of science and technology. The NLR that was given the new name in 1917 the Russian Public Library - was supposed to serve these purposes as well.

It is interesting to mention, that in November of 1917 the Head of the Soviet government Vladimir Lenin wrote a note "On the objectives of the Public Library in Petrograd" (Petrograd was the name of St. Petersburg in 1914-1924) in which he planned several measures in order to improve its work, including the establishment of the fixed work hours from 8 a.m. till 11 p.m., developing international book exchange and some others. ${ }^{14}$

\footnotetext{
12 Istoriya Gosudarstvennoj Publichnoj biblioteki im. M.E. SaltykovaShchedrina. 1963. Leningrad. (Lenizdat, 1963, 429-430)

${ }^{13}$ Efimova N.A. "Chitateli Publichnoj biblioteki v Peterburge i organizaciya ih obsluzhivaniya v 1814-1917 gg." in Trudy Gosudarstvennoj publichnoj biblioteki im. M.E. SaltykovaShchedrina. Vol.6(9). (Leningrad, 1958, 108-110)

14 Istoriya Gosudarstvennoj Publichnoj biblioteki im. M.E. SaltykovaShchedrina. 1963. Leningrad. (Lenizdat, 1963, 160-161)
}

magacina i omogućavanja čitateljima da dobiju beletristiku i neke druge vrste publikacija, NBR je uspjela povećati posjećenost i posljedično - opticaj od 15110 posjeta i 27587 posudbi 1852 . do 145 366 posjeta i 461968 posudbi $1900 .{ }^{12}$ Sve je to dovelo do povećanja uloge Biblioteke u akademskom, kulturnom i javnom životu Rusije.

U drugoj polovici 19. stoljeća ruski revolucionari kao Vladimir Lenjin i Georgij Plehanov, izvanredni ruski naučnici, umjetnici i kompozitori bili su među čitateljima Biblioteke.

Početkom 20. stoljeća nastavile su se razvijati sljedeće tendencije: 1896. - 1916. godine broj studenata među čitateljima Biblioteke bio je 33,8\%. Broj studenata smanjio se tek 1916. godine kada su mnogi od njih pozvani na služenje vojnog roka tokom Prvog svjetskog rata.

U razdoblju od 1896. do 1916. broj civila među čitateljima smanjio se s $9,8 \%$ na $6,8 \%$, vojni časnici - sa $6,9 \%$ na $2,8 \%$. Istodobno je rastao broj medicinskih radnika, učitelja, kao i inženjera i tehničkih specijalista. Povećavao se i broj čitateljica. ${ }^{13}$

Revolucija 1917. i Građanski rat 1918. - 1920. koji su uslijedili uzrokovali su značajne promjene $\mathrm{u}$ svim sferama života u Rusiji. Jedan od ciljeva Komunističke partije koja je došla na vlast bila je Kulturna revolucija koja je podrazumijevala likvidaciju nepismenosti, pripremu kvalificiranih stručnjaka za prerađivačku industriju i poljoprivredni sektor, kao i razvoj znanosti i tehnologije. NBR je dobila novo ime 1917. godine - Ruska javna knjižnica - trebala je služiti i u ove svrhe.

Zanimljivo je spomenuti da je u novembru 1917. šef sovjetske vlade Vladimir Lenjin napisao bilješku "O ciljevima Javne knjižnice u Petrogradu" (Petrograd je bio ime Sankt Peterburga 1914.-1924.) u kojoj je planirao nekoliko mjera kako bi poboljšali rad, uključujući uspostavljanje fiksnog radnog vremena od 8 do 23 sata, razvoj međunarodne razmjene knjiga i neke druge aktivnosti. ${ }^{14}$

Od 1918. publika se Biblioteke počela mijenjati. Vojnici Crvene armije i radnici postali su aktivni korisnici biblioteke zajedno sa naučnicima, stručnjacima i studentima. Uprkos mnogim poteškoćama i nedostatku obučenog osoblja 1921. NBR je

\footnotetext{
12 Istorija Gosudarstvennoj Publičnoj biblioteki im. Saltykova-Šedrina. 1963. Leningrad. (Lenizdat,1963, 429-430)

${ }^{13}$ Efimova N.A. 1958. "Čitateli Publičnoj biblioteki v Peterburge i organizacija ih obsluživanija v 1814-1917 gg." u Trudy Gosudarstvennoj publičnoj biblioteki im. M.E. Saltykova-Šedrina. T.6(9). (Leningrad, 1958, 108-110)

${ }^{14}$ Istorija Gosudarstvennoj Publičnoj biblioteki im. SaltykovaŠedrina.1963. Leningrad. (Lenizdat, 1963, 160-161)
} 
Since 1918 the audience of the Library started to change. Red Army soldiers and workers became active library users along with the scientists, professionals and students. Despite many difficulties and lack of trained personnel in 1921 the NLR already accepted the rules, according to which all the previously existing limitations have been abolished so that any citizen of 14 years and older could become the Library user. ${ }^{15}$ Soon the Library's reading rooms became crowded: people used to sit on the stairs, in the passages between the tables, on the floors. Many of the readers were students of different schools and courses. It was at that time, in the beginning of $1920 \mathrm{~s}$, when the discussion started in the NLR, on who should such big academic library serve and if there should be school pupils among its readers. In particular, there was an opinion that this category should either not be allowed to have access to the NLR, or get literature only from certain collections which would include textbooks and some other literature for studying. This discussion was interrupted by war of 1941-1945. Later a different solution for this problem has been found.

Changes in the work of the Library were caused by the serious changes in social and professional characteristics of its audience and widening of the readers' interests.

Whereas before the Soviet period there were almost no workers among the readers, by the middle of the 1920s dozens and hundreds of working class men were coming to the Library. In 1927821 workers registered in the NLR, in 1928 - 1592. In 1929 it was already 2806 people $(6,1 \%)$, and in $1930-3833$ people $(8,2 \%)$. By the end of the 1920 s metal workers and textile workers prevailed among the readers of the Library who belonged to the working class. Most of them came there for self-education. Social composition of studentship has also changed a lot, especially by the end of the 1920s. New representatives of the intelligentsia were also coming mainly from the working class or peasantry. Outstanding American writer Theodore Dreiser, who visited Public Library in 1927 wrote: "Now Russian proletarians come here to read, when previously they had been arrested for thirst for knowledge". ${ }^{16}$

Industrialization that was happening in the end of the 1920s and 1930s seriously influenced the audience of the Library and the service. There was an academic reading room for academic workers and specialists where the comfortable conditions were created $-\mathrm{a}$ već prihvatila pravila prema kojima su ukinuta sva prethodno postojeća ograničenja kako bi svaki građanin stariji od 14 godina mogao postati korisnik Biblioteke. ${ }^{15}$ Ubrzo su čitaonice Biblioteke postale pretrpane: ljudi su znali sjediti na stepenicama, u prolazima između stolova i na podovima. Mnogi su čitatelji bili učenici različitih škola i tečajeva. Bilo je to početkom 1920tih, kada je u NBR-u započela rasprava o tome kome treba služiti tako velika akademska biblioteka i treba li među njezinim čitateljima biti učenika škole. Konkretno, postojalo je mišljenje da se ovoj kategoriji ili ne smije dopustiti pristup NBR-u, ili se može dobiti literatura samo iz određenih zbirki koje uključuju udžbenike i neku drugu literaturu za učenje. Ova je rasprava prekinuta ratom 1941.-1945. Kasnije je pronađeno drugačije rješenje za ovaj problem.

Promjene u radu Biblioteke uzrokovane su ozbiljnim promjenama u socijalnim i profesionalnim karakteristikama njezine publike $i$ širenjem interesa čitatelja.

Prije sovjetskog perioda među čitateljima gotovo da nije bilo radnika, sredinom 1920-ih desetine i stotine radnika iz radničke klase dolazili su u Biblioteku. 1927. u NBR-u se upisao 821 radnik, 1928. - 1592. U 1929. već je bilo 2806 ljudi (6,1\%), a 1930 - 3833 ljudi $(8,2 \%)$. Do kraja 1920-ih među čitateljima Biblioteka koji su pripadali radničkoj klasi prevladavali su metalski i tekstilni radnici. Većina ih je tamo došla radi samoobrazovanja. Socijalni sastav studentskog staža također se mnogo promijenio, posebno krajem 1920-ih. Novi predstavnici intelektualaca također su dolazili uglavnom iz radničke klase ili seljaštva. Izvrsni američki književnik Theodore Dreiser, koji je posjetio Javnu knjižnicu 1927. godine, napisao je: "Sada ruski proleteri dolaze ovamo čitati, a prije su bili hapšeni zbog žeđi za znanjem". ${ }^{16}$

Industrijalizacija koja se događala krajem 1920-ih i 1930-ih ozbiljno je utjecala na korisnike Biblioteke i službe. Postojala je akademska čitaonica za akademske radnike i stručnjake u kojoj su stvoreni ugodni uslovi - mogućnost brzog dobijanja savremenih stranih časopisa, četiri mjesta za specijaliziranu tematsku literaturu, itd. Sredinom 1930-ih ova je kategorija činila 30\% svih čitatelja. Svi ostali čitatelji - uglavnom studenti - radili su u javnoj čitaonici.

Budući da je bilo nemoguće uslužiti sve čitatelje u glavnoj zgradi, odlučeno je organizirati podružnice

\footnotetext{
15 Ibid, 185

${ }^{16}$ Ibid, 186
} 
possibility to quickly receive modern foreign periodicals, four specialized subject-matter literature issue points etc. In the middle of the 1930s this category was $30 \%$ of all readers. All other readers - mainly, students - worked in the public reading room.

As it was impossible to serve all the readers in the main building, it was decided to organize the NLR's branch offices in relatively close proximity from it. Thus, a branch office "Library of Local Economies" was formed, with an audience of policy planners, economists, diploma students. Another branch office - "Library of the Youth" had a well-selected collection of fiction and study materials, and the branch office for teenagers, situated in the Palace of the Pioneers, was very popular among the 6 to 10 year school pupils. An office branch "World Literature Library" provided engineers and workers from more than 25 factories with foreign technical literature and organized the courses of foreign languages. There was also a branch office in the Central Park of Culture and Recreation, as well as in one of the further rural areas of Leningrad region. In general, in 1930 s non-stationary service covered $25 \%$ of the Library audience. ${ }^{17}$

Overall, by the 1940s the attendance of the Library counted 1024161 visits, twice as much as in 1927, and the amount of loans increased to 3264781 volumes, 58\% more than in 1927.

In 1941 the Great Patriotic War started (19411945); from September of 1941 till January of 1944 Leningrad (name of the city in 1924-1991) was under siege. The most valuable part of the collection was evacuated, but the NLR didn't stop serving the readers even amidst cold, famine and practically daily artillery attacks and bombings. During the war the Library served 42597 people who visited it 463846 times and received 1474408 documents. People of different occupations turned to the Library: engineers, technical specialists and workers, doctors and nurses, officers and soldiers, teachers and students, scientists, journalists and writers, performers, artists, architects. Amount of military specialists, doctors, and nurses among the readers increased drastically (in 1942 they were the $40 \%$ of the readers). Library was also popular among the lecturers and the radio and cinema specialists.

Materials on issues of the defense of the city were often needed: books about urban combat, building defensive constructions, arrangement, equipment and exploitation of hospitals, garages, asylums,
NBR-a u relativno neposrednoj blizini od nje. Tako je osnovana podružnica "Biblioteka lokalnih gospodarstava", sa korisnicima - političkim planerima, ekonomistima, diplomantima. Druga podružnica „Biblioteka mladih“ imala je dobro odabranu zbirku beletristike i studijskog materijala, a podružnica za tinejdžere, smještena u Palači pionira, bila je vrlo popularna među učenicima od 6 do 10 godina. Uredski ogranak "Svjetska književna biblioteka" opskrbio je inženjere i radnike iz više od 25 tvornica stranom tehničkom literaturom i organizirao kurseve stranih jezika. Također je postojala podružnica u Centralnom parku kulture i rekreacije, kao i u jednom od daljnjih ruralnih područja Lenjingradske regije. Općenito, 1930-ih nestacionarna služba pokrivala je $25 \%$ korisnika Biblioteke. ${ }^{17}$

Sveukupno, do 1940-ih posjećenost Biblioteke brojila je 1024161 posjeta, dvostruko više nego 1927. godine, a iznos posudbi povećao se na 3264781 knjiga, $58 \%$ više nego 1927 . godine.

1941. započeo je Veliki patriotski rat (1941.-1945.); od septembra 1941. do januara 1944. Lenjingrad (ime grada 1924. - 1991.) bio je pod opsadom. Najvrjedniji dio zbirke evakuiran je, ali NBR nije prestala služiti čitateljima ni usred hladnoće, gladi i praktički svakodnevnih topničkih napada i bombardiranja. Tokom rata Biblioteka je opsluživala 42 597 ljudi koji su je posjetili 463846 puta i primili 1 474408 dokumenata. Biblioteci su se obraćali ljudi različitih zanimanja: inženjeri, tehnički stručnjaci i radnici, doktori i medicinske sestre, časnici i vojnici, učitelji i studenti, naučnici, novinari i književnici, izvođači, umjetnici, arhitekti. Broj vojnih specijalista, doktora i medicinskih sestara među čitateljima drastično se povećao (1942. oni su činili $40 \%$ čitatelja). Biblioteka je bila popularna i među predavačima te radijskim $i$ kino stručnjacima.

Često su bili potrebni materijali o pitanjima odbrane grada: knjige o urbanim borbama, gradnji odbrambenih konstrukcija, uređenju, opremi i eksploataciji bolnica, garaža, azila, skladišta itd. Sudionici partizanskog pokreta bili su i čitatelji Biblioteke. Primjerice, 1942. godine zapovjednik jedne od partizanskih jedinica koristio je ilustrativni materijal o Pskovu, potreban za borbenu misiju.

Medicinske radnike zanimala je literatura o borbi protiv gladi, divljih jestivih biljaka i kalorijske sposobnosti glukoze. U proljeće 1942. godine, kada su se parkovi i trgovi Lenjingrada počeli pretvarati u povrtnjake, povećala se potražnja za literaturom o 
warehouses etc. Participants of the partisan movement also were the readers of the Library. For example, in 1942 the commanding officer of one of the partisan units used the illustrative material about Pskov, needed for the combat mission.

Medical workers were interested in literature on fight against hunger, wild edible plants, and calorific capacity of glucose. In the spring of 1942, when the parks and squares of Leningrad started to turn into vegetable gardens, demand for literature on gardening and growing mushrooms increased. ${ }^{18} \mathrm{He}-$ roic work of the Library's staff on saving the unique treasures and serving the readers made it into the history of USSR's fight against fascism.

After the war the USSR started to repair the damage that Germany caused to its economy; enterprises, academic institutions and higher education institutions that had been evacuated inland came back to Leningrad. By the end of the war the main reading rooms have been opened and their supplementary collections have been put into order. In 1946 the amount of readers and the circulation increased one-and-a-half times comparing to 1945 , and the amount of visits was almost twice as many. In 1948 the amount of readers reached the pre-war level 74 thousand people. In 1950 Children-and-Youth Hall was organized for the schoolchildren from 13 to 17 years of age. A good supplementary collection and experienced librarians offered their help in the search of the literature and working with it.

In the following years a steady growth of all performance indicators has been registered in the NLR.

It was during the post-war period when the tendency of prevalence of readers with higher education occurred. This tendency existed until the 1990s.

Next table demonstrates the correlation between the main groups of readers and the dynamic of their growth in $1950-1962:{ }^{19}$ vrtlarstvu i uzgoju gljiva. ${ }^{18}$ Herojsko djelo osoblja Biblioteke na spašavanju jedinstvenog blaga i opsluživanju čitatelja ušlo je u historiju borbe SSSR-a protiv fašizma.

Nakon rata SSSR je počeo popravljati štetu koju je Njemačka nanijela gospodarstvu; preduzeća, akademske institucije i visokoškolske ustanove koje su evakuirane u unutrašnjost vratile su se $u$ Lenjingrad. Krajem rata otvorene su glavne čitaonice i dovedene u red njihove dopunske zbirke. 1946. broj čitatelja i pozajmice povećao se jedan i po put u odnosu na 1945., a posjeta je bila gotovo dvostruko veća. 1948. godine broj čitatelja dosegnuo je predratnu razinu - 74 hiljade ljudi. 1950. godine organizovana je Dječja i omladinska dvorana za školarce od 13 do 17 godina. Dobra dopunska zbirka i iskusni bibliotekari su ponudili pomoć u pretraživanju literature i radu s njom.

Sljedećih godina u NBR-u je zabilježen stalni rast svih pokazatelja uspješnosti.

Tokom poslijeratnog razdoblja dogodila se tendencija porasta visoko obrazovanih čitatelja. Ta je tendencija postojala sve do 1990-ih.

Sljedeća tablica prikazuje povezanost glavnih skupina čitatelja i dinamiku njihovog rasta u 1950. $1962 . .^{19}$

\begin{tabular}{|c|c|c|c|c|c|c|c|c|}
\hline \multirow[b]{2}{*}{$\begin{array}{l}\text { Categories of readers } \\
\text { Kategorije čitatelja }\end{array}$} & \multicolumn{2}{|c|}{1950} & \multicolumn{2}{|c|}{1955} & \multicolumn{2}{|c|}{1960} & \multicolumn{2}{|c|}{1962} \\
\hline & $\begin{array}{c}1000 \\
\text { people / ljudi }\end{array}$ & $\%$ & $\begin{array}{c}1000 \\
\text { people / ljudi }\end{array}$ & $\%$ & $\begin{array}{c}1000 \\
\text { people / ljudi }\end{array}$ & $\%$ & $\begin{array}{c}1000 \\
\text { people / } \\
\text { ljudi }\end{array}$ & $\%$ \\
\hline Students and pupils / Studenti i učenici & 45,2 & 62,0 & 46,2 & 51,6 & 39,8 & 38,2 & 38,1 & 33,8 \\
\hline $\begin{array}{l}\text { Specialists with higher education / } \\
\text { Stručnjaci s visokim obrazovanjem }\end{array}$ & 22,1 & 30,4 & 31,7 & 35,5 & 43,3 & 40,6 & 47,1 & 42,0 \\
\hline $\begin{array}{l}\text { Workers and employees without higher } \\
\text { education / Radnici i zaposlenici bez } \\
\text { visokog obrazovanja }\end{array}$ & 5,5 & 7,6 & 11,6 & 12,9 & 22,1 & 21,2 & 27 & 24,2 \\
\hline
\end{tabular}

\footnotetext{
18 Ibid, 297

19 Ibid, 318
} 
Also, before the 1990 the majority of specialists with higher education among the readers were engineers and technicians working for research centres, technical institutions, manufacturing enterprises. For instance, from 171251 readers with higher education who registered in the Library in 1985 1990 about $70 \%$ represented such fields as industry, transport, communications, construction, design and scientific organizations.

The dissolution of the USSR led to closing of many factories and plants, design and scientific organizations, increase in the number of students - that was in turn caused by increase in the number of education institutions including non-state ones. This table demonstrates this tendency:
Također, prije 1990. većinu stručnjaka s visokim obrazovanjem među čitateljima su činili inženjeri i tehničari koji su radili za istraživačke centre, tehničke institucije i proizvodna preduzeća. Na primjer, od 171251 čitatelja s visokim obrazovanjem koji su se učlanili u Biblioteku od 1985. do 1990. godine, oko $70 \%$ predstavljalo je područja poput industrije, prometa, veza, građevine, dizajna i naučnih organizacija.

Raspad SSSR-a doveo je do zatvaranja mnogih fabrika i industrija, dizajnerskih i naučnih organizacija, povećanja broja studenata - što je zauzvrat uzrokovano povećanjem broja obrazovnih institucija, uključujući i nedržavnih. Ova tablica pokazuje ovu tendenciju:

Upis čitatelja 1985. - 1995. ${ }^{20}$

Registration of readers in $1985-1995 .^{20}$

\section{Upis citatelja 1985. - 1995.}

\begin{tabular}{|l|c|c|c|c|}
\hline & $1985-1990$ & $\begin{array}{c}\% \\
\text { of the total number / od ukupnog } \\
\text { broja }\end{array}$ & $1991-1995$ & $\begin{array}{c}\% \\
\text { of the total number / od ukupnog } \\
\text { broja }\end{array}$ \\
\hline $\begin{array}{l}\text { Readers with higher education / } \\
\text { Visoko obrazovani čitatelji }\end{array}$ & 171251 & 59,9 & 125300 & 47,2 \\
\hline $\begin{array}{l}\text { Students and readers without higher } \\
\text { education / Studenti i čitatelji bez } \\
\text { visokog obrazovanja }\end{array}$ & 95248 & 33,3 & 123014 & 46,4 \\
\hline Readers aged / Čitatelji dobi 14-18 & 14607 & 5,1 & 14863 & 5,6 \\
\hline
\end{tabular}

In 1995-2000 this tendency continued to develop. Also, a slight increase in the amount of readers with higher education took place, generally because of the engineers, who studied for other specialties, such as accountant or economist. The readers who needed literature on humanities prevailed among the students. ${ }^{21}$

Of course, in XXI century the work conditions improved: automated working stations were available, as well as digital library and catalogue, virtual enquiry service and databases etc. Nevertheless, the demand for hard copies of books is still rather high. Talking about the readers of the NLR in XXI century, the majority of them were students and postgraduates. Among the reasons are not convenient working hours of university libraries and lack of needed literature there, and also the need to check graduation qualification works using the system "Antiplagiat" and to work with the original sources. For example, in 2016 the NLR registered 29,7 new library cards (a library card is valid for 5 years), from which $29 \%$ have been issued to people with

\footnotetext{
${ }^{20}$ Rossijskaya nacional'naya biblioteka. 1918-1995 gg. 2002. (Saint Petersburg, 2002, 158)

${ }^{21}$ Rossijskaya nacional'naya biblioteka. 1996-2000 gg. 2003. (Saint Petersburg, 2003, 43-45)
}

1995.-2000. ova se tendencija nastavila razvijati. Također, dogodio se lagani porast broja čitatelja s visokim obrazovanjem, općenito zbog inženjera koji su studirali za druge specijalnosti, npr. za računovođu ili ekonomistu. Među studentima su prevladavali čitatelji kojima je bila potrebna literatura humanističkih nauka. ${ }^{21}$

Naravno, u 19. stoljeću poboljšali su se uslovi rada: bile su dostupne automatizirane radne stanice, digitalna biblioteka i katalog, virtualna služba upita, baze podataka itd. Ipak, potražnja za štampanim primjercima knjiga još je uvijek velika.

Govoreći o čitateljima NBR-a u 21. stoljeću, većina njih bili su studenti i postdiplomci. Među razlozima su neprikladno radno vrijeme univerzitetskih biblioteka i nedostatak potrebne literature, kao i potreba za provjerom diplomskih radova pomoću sistema "Antiplagiat" i rada s izvornim izvorima. Primjerice, 2016. godine NBR je izdao 29,7 novih članskih karti (članska karta vrijedi 5 godina), od čega je $29 \%$ izdano osobama s visokim obrazovanjem, $68 \%$ - studentima i osobama sa srednjim obrazova-

\footnotetext{
${ }^{20}$ Rossijskaja nacional'naja biblioteka. $1918-1995$ gg. 2002. (SanktPeterburg, 2002, 158)

${ }^{21}$ Rossijskaja nacional'naja biblioteka. 1996-2000 gg. 2003. (SanktPeterburg, 2003, 43-45)
} 
higher education, $68 \%$ - to students and people with secondary education, $3 \%$ to school pupils younger than 17 years old. Nowadays the majority of readers of the NLR work with materials on humanitarian studies. The highest demand is for literature on philology, history, economics, culture studies, law studies, medicine etc. and only $20 \%$ of the inquiries are for technical literature. ${ }^{22}$

This is what the audience of the NLR used to be and is today, and that is how the Library has actively been supporting the development of science, culture and education in Russia throughout its existence.

\section{Bibliography}

- Efimova N.A. 1958. "Chitateli Publichnoj biblioteki v Peterburge i organizaciya ih obsluzhivaniya v 1814-1917 gg." in Trudy Gosudarstvennoj publichnoj biblioteki im. M.E. Saltykova-Shchedrina. Vol.6(9). (Leningrad, 1958)

- Grin C.I., Tret'yak A.M. 1998. Publichnaya biblioteka glazami sovremennikov (1795-1917). (Saint Petersburg, 1998)

- Istoriya Gosudarstvennoj Publichnoj biblioteki im. M.E. Saltykova-Shchedrina. 1963. Leningrad. (Lenizdat, 1963)

- Rossijskaya nacional'naya biblioteka. 19181995 gg. 2002. (Saint Petersburg, 2002)

- Rossijskaya nacional'naya biblioteka. 19962000 gg. 2003. (Saint Petersburg, 2003)

- Rossijskaya nacional'naya biblioteka v 2016 g. Publichnyj otchet. 2017. (Saint Petersburg, 2017) njem, $3 \%$ učenicima mlađim od 17 godina. Danas većina čitatelja NBR-a radi s materijalima o humanitarnim studijama. Najviše se potražuje literatura iz filologije, historije, ekonomije, studija kultura, pravnih studija, medicine itd., A samo $20 \%$ upita odnosi se na tehničku literaturu. ${ }^{22}$

Ovo je ono što je čitateljska publika NBR-a bila i što je i danas, i tako je Biblioteka aktivno podržavala razvoj nauke, kulture i obrazovanja u Rusiji kroz svoje postojanje.

\section{Bibliografija}

- Efimova N.A. 1958. "Čitateli Publičnoj biblioteki v Peterburge i organizacija ih obsluživanija v 1814-1917 gg.” u Trudy Gosudarstvennoj publičnoj biblioteki im. M.E. Saltykova-Šedrina. T.6(9). (Leningrad, 1958)

- Grin C.I., Tret'jak A.M. 1998. Publičnaja biblioteka glazami sovremennikov (1795-1917). (Sankt-Peterburg,1998.)

- Istorija Gosudarstvennoj Publičnoj biblioteki im. Saltykova-Šedrina. 1963. Leningrad. (Lenizdat, 1963)

- Rossijskaja nacional'naja biblioteka. 1918-1995 gg. 2002. (Sankt-Peterburg, 2002)

- Rossijskaja nacional 'naja biblioteka. 1996-2000 gg. 2003. (Sankt-Peterburg, 2003)

- Rossijskaja nacional'naja biblioteka v 2016 g. Publičnyj otčet. 2017. (Sankt-Peterburg, 2017) 